\title{
PENGARUH PERSEPSI PESERTA DIDIK ATAS KOMPETENSI SOSIAL GURU TERHADAP HASIL BELAJAR DI SMKN 12 BEKASI
}

\author{
Neni Nur Aini ${ }^{1}$, Rosalina Dewi Heryani ${ }^{2}$ \\ Universitas Indraprasta PGRI, Jakarta, Indonesia ${ }^{12}$ \\ neninurani01@ gmail.com ${ }^{1}$,rosalina.dewi7@ gmail.com²
}

\section{Received: 05 Maret 2021 \\ Revised: 07 Maret 2020 \\ Accepted: 11 Maret 2020}

\begin{abstract}
Penelitian bertujuan untuk mengetahui pengaruh persepsi peserta didik atas kompetensi sosial guru terhadap hasil belajar di SMKN 12 Bekasi. Menggunakan metode kuantitatif, jumlah responden sebanyak 63 peserta didik dengan teknik random sampling. Pengumpulan data melalui observasi, kuesioner, dan dokumentasi. Hasil penelitian menunjukkan nilai koefisien korelasi sebesar 0,401 menunjukkan ada hubungan yang sedang antara persepsi peserta didik atas kompetensi sosial guru dengan hasil belajar. Koefisien determinasi sebesar $16,08 \%$ yang artinya persepsi peserta didik atas kompetensi sosial guru menyumbangkan kontribusi sebesar 16,08\% sedangkan sisanya 83,92\% dipengaruhi oleh faktor lain. Hasil pengujian hipotesis menunjukkan nilai $\mathrm{t}_{\text {hitung }}>\mathrm{t}_{\text {tabel }}$ yaitu 3,418> 1,670 yang berarti terdapat pengaruh persepsi peserta didik atas kompetensi sosial guru terhadap hasil belajar di SMKN 12 Bekasi. Temuan ini memberikan keyakinan bahwa persepsi peserta didik memberikan pengaruh positif terhadap hasil belajar. Peserta didik mampu mengoptimalkan seluruh kemampuannya dan mereduksi hal-hal negatif yang menimpanya, serta mengubahnya menjadi energi positif yang akan membangkitkan semangat belajar peserta didik.
\end{abstract}

Keywords: Kompetensi Sosial; Guru; Hasil Belajar

Heryani, rosalina.dewi7@gmail.com, +62 8568688130

How to Cite: Aini, N. N., \& Heryani, R. D. (2021). Pengaruh Persepsi Peserta Didik Atas Kompetensi Sosial Guru Terhadap Hasil Belajar Di SMKN 12 Bekasi. Research and Development Journal of Education, $7(1), 116-125$.

\section{INTRODUCTION}

Aktivitas kehidupan manusia selalu melibatkan proses pendidikan, baik ketika seseorang melaksanakan aktivitas sendiri maupun berkelompok dan mereka akan selalu bersinggungan dengan proses belajar. Dengan demikian manusia tidak bisa melepaskan diri dari kegiatan belajar. Belajar tidak terbatas usia, ruang, dan waktu. Melalui belajar manusia akan memperoleh pengetahuan, pengalaman dan perilaku baru, sehingga manusia dapat mengadakan penyesuaian dengan lingkungan sekelilingnya.

Di sekolah hal itu diperoleh peserta didik selama proses pembelajaran sampai mencapai tujuan akhirnya, yaitu hasil belajar peserta didik. Hasil belajar mengandung makna keberhasilan peserta didik dalam kegiatan belajarnya. Kegiatan proses belajar mengajar hasilnya berupa tiga ranah dari teori Bloom. Sehingga pencapaian hasil belajar berkaitan erat dengan kegiatan belajar peserta didik. Dengan bahasa sederhana, hasil belajar adalah hasil yang diperoleh peserta didik selama mengikuti program belajar dalam rangka menyelesaikan suatu program pendidikan.

Guru sebagai makhluk sosial selalu berinteraksi dan berkomunikasi, baik di sekolah maupun lingkungannya. Oleh sebab itu, guru harus memiliki kompetensi sosial 
yang memadai. Keberhasilan guru dalam menjalankan tugasnya tidak terlepas dari lingkungan tempat mengajar. Dari sanalah suasana hubungan yang serasi dan harmonis antara peserta didik, rekan sejawat, tenaga kependidikan, orangtua, dan lingkungan masyarakat sekitar sangat menunjang kompetensi sosial guru.

Lembaga pendidikan di Jawa Barat khususnya wilayah Bekasi memiliki banyak lembaga pendidikan. Hal ini dibuktikan dengan adanya sekolah negeri maupun swasta mulai dari tingkat SD, SMP, SMA, dan SMK yang semakin meningkat setiap tahunnya. Dengan demikian pendidik harus mengembangkan kompetensi yang dimilikinya serta mengkondisikan dirinya dalam setiap situasi. Namun masih ditemukan proses pembelajaran yang kurang kondusif di ruang kelas. Hal inilah yang menjadi penghambat kelancaran proses pembelajaran dan menyebabkan peserta didik mendapatkan hasil yang kurang memuaskan.

Berdasarkan hasil observasi awal di SMKN 12 Bekasi ditemukan gejala atau fenomena seperti adanya sebagian peserta didik yang kurang berminat untuk mengikuti pelajaran di kelas. Hal ini terlihat saat proses pembelajaran berlangsung peserta didik nampak malas, tidak bersemangat dalam mengikuti pelajaran, tidak mau memperhatikan guru pada saat menerangkan, seringnya peserta didik izin keluar kelas saat proses pembelajaran berlangsung dan ada peserta didik tidak peduli dengan lingkungan sekitar.

Penelitian serupa sudah pernah dilakukan, namun terdapat perbedaan yaitu perbedaan variabel bebas dan jumlah variabelnya, teknik analisis data dan tempat penelitiannya (Karlina dan Iswadi, 2018). Perbedaan pada variabel bebas, teknik sampling, teknik analisis data dan tempat penelitiannya (Syaidah dkk, 2018). Dan yang terakhir perbedaan pada variabel bebas, teknik analisis data, dan tempat penelitiannya (Marhento, 2011).

\section{LITERATURE REVIEW}

\section{Kompetensi Sosial Guru}

\section{Pengertian Kompetensi Sosial}

Menurut Jihad (2013:42), kompetensi sosial merupakan kemampuan yang harus dimiliki guru untuk melakukan komunikasi, bergaul dengan efektif antara peserta didik, rekan sejawat, orangtua, dan masyarakat sekitar. Misalnya berdiskusi tentang masalah yang dihadapi peserta didik dan mencari solusinya. Guru memberikan informasi tentang bakat, minat dan kemampuan peserta didik kepada orangtua. Menurut Musfah (2011:52), terkait dengan kompetensi guru menjelaskan bahwa guru wajib memiliki jiwa sosial tinggi, mudah bergaul, gemar menolong, tidak bersikap tertutup dan acuh tak acuh.

Berdasarkan pengertian kompetensi sosial guru yang telah disebutkan, disimpulkan kompetensi sosial guru merupakan kemampuan dan kecakapan guru ketika berkomunikasi dan berinteraksi pada saat proses pembelajaran dan di masyarakat sekitar.

2. Karakteristik Kompetensi Guru

Menurut Sagala (2013:23), seorang guru dinilai memiliki kompetensi apabila guru mampu mengemban amanah dengan sebaiknya, melaksanakan perannya secara berhasil, tercapainya tujuan pendidikan (tujuan instruksional), dan menjalankan peran dalam proses belajar mengajar di kelas.

Dari penjelasan tersebut disimpulkan bahwa karakteristik kompetensi guru merupakan kemampuan dan keahlian dalam bidang keguruan yang wajib dimiliki guru profesional yang telah melalui proses pendidikan dengan baik. 


\section{Ciri-Ciri Kompetensi Sosial Guru}

Menurut Payong (2011:289), menyebutkan ciri-ciri kompetensi sosial antara lain bekerja sama dengan semua pihak untuk meningkatkan kualitas diri dalam rangka melaksanakan tugas dan tanggung jawabnya, dan ikut serta berperan serta dalam asosiasi pengawas satuan pendidikan. Sedangkan Menurut Daryanto (2015:84), mengemukakan bahwa kompetensi sosial guru dapat dilihat dari kemampuannya bersosialisasi dan bekerja sama dengan seluruh warga sekolah.

Berikut ciri-ciri kompetensi sosial guru yang harus dikuasai antara lain berkomunikasi lisan dan tulisan. Menggunakan teknologi, informasi, dan komunikasi dengan efektif. Berinteraksi secara santun dan efektif dengan warga sekolah. Bertindak sesuai norma yang berlaku dimasyarakat. Menunjukkan pribadi dewasa dan memberi keteladanan. Memiliki etos kerja, tanggung jawab tinggi dan bangga menjadi seorang guru.

\section{Hasil Belajar}

\section{Pengertian Belajar}

Belajar merupakan proses perubahan perilaku manusia mencakup sesuatu yang dipikirkan dan dikerjakan. Belajar penting dilakukan untuk mengembangkan kebiasaan sikap, keyakinan, tujuan, kepribadian, bahkan persepsi manusia. Belajar merupakan proses dan usaha yang dilakukan individu untuk memperolah perubahan tingkah laku secara keseluruhan, sebagai hasil pengalaman individu dalam berinteraksi dengan lingkungannya (Slameto, 2010:2).

Menurut Aunurrahman (2010:35), belajar adalah usaha sadar yang dilakukan individu dalam mengubah tingkah laku melalui latihan dan pengalaman meliputi aspek kognitif, afektif, dan psikomotorik untuk memperoleh tujuan.

\section{Jenis-Jenis Belajar}

Menurut Slameto (dalam Lestari, 2013:30), ada beberapa jenis belajar yaitu belajar bagian (part learning, fractioned learning). Belajar dengan wawasan (learning by insight). Belajar diskriminatif (discriminatif learning). Belajar global (global whole learning). Belajar insidental (incidental learning). Belajar laten (latent learning). Belajar mental (mental learning). Belajar verbal (verbal learning).

3. Prinsip-Prinsip Belajar

Menurut Sardiman (2012:24-25), ada beberapa prinsip belajar antara lain belajar sejatinya berkaitan dengan potensi manusia dan perilakunya. Belajar membutuhkan proses dan tahapan serta kematangan diri. Belajar akan efektif jika didorong oleh motivasi yang berasal dari dalam. Belajar merupakan proses percobaan dan pembiasaan. Kemampuan belajar peserta didik perlu diperhitungkan untuk menentukan isi pembelajaran. Belajar dilakukan dengan tiga cara yaitu diajar secara langsung, dengan melakukan kontrol dan pengalaman langsung, serta pengenalan atau peniruan. Belajar melalui praktik akan lebih efektif dalam membentuk sikap, keterampilan, berpikir kritis, bila dibandingkan dengan hapalan. Pengalaman peserta didik akan mempengaruhi kemampuan belajarnya. Bahan ajar yang bermakna lebih mudah menarik untuk dipelajari. Dengan mendiagnosa kesalahan dan keberhasilan peserta diidk dapat membantu kelancaran dan menumbuhkan gairah belajar. Belajar dengan beragam tugas, berdiskusi, atau praktik langsung akan meningkatkan hasil belajar. 


\section{Pengertian Hasil Belajar}

Menurut Sudjana (2017:3), hasil belajar peserta didik sejatinya merupakan perubahan tingkah laku yang lebih luas mencakup kognitif, afektif, dan psikomotorik. Sedangkan menurut Dimyati dan Mudjiono (2013:3-4), hasil belajar merupakan suatu interaksi tindakan belajar dan mengajar. Bagi guru mengajar diakhiri dengan evaluasi hasil belajar, sedangkan bagi siswa hasil belajar merupakan puncak proses belajar.

Maka dapat disimpulkan hasil belajar merupakan kemampuan yang dimiliki peserta didik setelah menerima pengalaman belajar. Kemampuan tersebut mencakup afektif, kognitif, dan psikomotorik. Jadi hasil belajar merupakan tercapainya tujuan belajar dan sebagai produk dari proses belajar.

5. Faktor-Faktor yang Memengaruhi Hasil Belajar

Menurut Slameto ( 2010:53), faktor yang memengaruhi hasil belajar antara lain :

a. Faktor intern meliputi faktor jasmaniah (kesehatan, cacat tubuh), faktor psikologis (intelegensi, perhatian, bakat, minat, motif, kesiapan, kematangan), dan faktor kelelahan.

b. Faktor ekstern meliputi faktor keluarga (pola orangtua mendidik, suasana rumah, hubungan antar keluarga, keadaan ekonomi keluarga, pemahaman orangtua, latar belakang kebudayaan), faktor sekolah (teknik mengajar, hubungan guru dengan peserta didik/peserta didik dengan peserta didik, kurikulum, kedisiplinan di sekolah, alat peraga/pengajaran, lamanya waktu belajar di sekolah, standar pelajaran, keadaan gedung, tugas rumah), faktor masyarakat (kegiatan peserta didik dalam bermasyarakat, dan bergaul.

\section{METHODS}

\section{Jenis Penelitian}

Menggunakan penelitian deskriptif dengan pendekatan kuantitatif yaitu mengungkapkan pengaruh antar variabel yang dinyatakan dalam angka serta menjelaskannya dengan membandingkan dengan teori-teori yang telah ada, dan menggunakan teknik analisis yang sesuai dengan variabel penelitian.

2. Populasi dan Sampel

Populasinya adalah peserta didik kelas XI SMKN 12 Bekasi yang berjumlah 169 peserta didik. Sampel dihitung dengan rumus slovin menggunakan margin error $10 \%$ sehingga diperoleh sampel 63 peserta didik. Teknik sampling yang digunakan adalah random sampling.

3. Teknik Pengumpulan Data

a. Observasi.

Obeservasi dilakukan oleh peneliti dengan langsung berkunjung ke SMKN 12 Bekasi, dalam prosesnya peneliti menggunakan bantuan lembar observasi dengan memberikan tanda cek list.

b. Kuesioner.

Kuesioner digunakan untuk memperoleh data untuk variabel persepsi peserta didik atas kompetensi sosial guru. Kuesioner berisi 20 butir pernyataan yang telah valid dan reliable, menggunakan skala likert. 
c. Dokumentasi

Dokumentasi yang digunakan antara lain buku, jurnal, dan juga beberapa dokumen sekolah. Untuk hasil belajar diambil dari Penilaian Tengah Semester Ganjil.

4. Teknik Analisis Data

a. Regresi Linier Sederhana

Untuk mengetahui hubungan fungsional antara variabel persepsi peserta didik atas kompetensi sosial guru terhadap hasil belajar. Rumusnya sebagai berikut :

$$
\mathrm{Y}=\mathrm{a}+\mathrm{bX}
$$

Adapun koefisien a dan $\mathrm{b}$ dapat dicari dengan menggunakan rumus sebagai berikut :

b. Koefisien Korelasi

$$
\begin{aligned}
& \mathrm{a}=\frac{\left(\sum Y\right)\left(\sum \boldsymbol{X}^{2}\right)-\left(\sum X\right)\left(\sum X Y\right)}{\boldsymbol{n} \cdot\left(\sum \boldsymbol{X}^{2}\right)-\left(\sum X\right)^{2}} \\
& \mathrm{~b}=\frac{\boldsymbol{n} \cdot\left(\sum X Y\right)-\left(\sum X\right)\left(\sum \boldsymbol{Y}\right)}{\boldsymbol{n} \cdot\left(\sum \boldsymbol{X}^{2}\right)-\left(\sum X\right)^{2}}
\end{aligned}
$$

Untuk mengetahui seberapa kuat hubungan variabel persepsi peserta didik atas kompetensi sosial guru dengan hasil belajar. Rumusnya sebagai berikut :

$$
\frac{\left(n \cdot \sum \boldsymbol{X} \boldsymbol{Y}\right)-\left(\sum \boldsymbol{X}\right)\left(\sum \boldsymbol{Y}\right)}{\sqrt{\left\{\boldsymbol{n} \cdot \sum \boldsymbol{X}^{2}-\left(\sum \boldsymbol{X}\right)^{2}\right\}\left\{n \cdot \sum \boldsymbol{Y}^{2}-\left(\sum \boldsymbol{Y}\right)^{2}\right\}}}
$$

Kemudian untuk menginterpretasikan kuat atau tidaknya hubungan, digunakan pedoman berikut ini :

Tabel 1

Interpretasi Koefisien Korelasi

\begin{aligned} & \hline Interval Koefisien Tingkat Hubungan \\ & \hline $0,00-0,19$ Sangat Rendah \\ & $0,20-0,39$ Rendah \\ & $0,40-0,59$ Sedang \\ & $0,60-0,79$ Kuat \\ & $0,80-1,00$ Sangat Kuat \\ & \hline\end{aligned}

Sumber: Sugiyono, 2015:231

c. Koefisien Determinasi

Untuk mengetahui seberapa besar kontribusi variabel persepsi peserta didik atas kompetensi kompetensi sosial guru terhadap hasil belajar. Rumusnya sebagai berikut :

d. Pengujian Hipotesis

$$
\mathrm{KD}=\mathrm{r}^{2} \times 100 \%
$$

Untuk menguji hipotesis digunakan rumus sebagai berikut :

Berlaku hipotesis sebagai berikut :

$$
t_{\text {hitung }}=\frac{r \sqrt{n-2}}{\sqrt{1-r^{2}}}
$$

$$
\begin{aligned}
& \mathrm{H}_{0}: \rho=0 \\
& \mathrm{H}_{\mathrm{a}}: \rho \neq 0
\end{aligned}
$$

Langkah selanjutnya adalah menentukan nilai $\mathrm{t}_{\text {tabel }}$ yaitu $\mathrm{dk}=\mathrm{n}-2$, uji 2 sisi $\alpha=10 \%$ atau 0,1 . Setelah itu nilai $\mathrm{t}_{\text {hitung }}$ dibandingkan dengan nilai $\mathrm{t}_{\text {tabel. }}$.

Ketentuan :

1) Jika $t_{\text {hitung }}>t_{\text {tabel }}$, maka $H_{0}$ ditolak dan $H_{1}$ diterima artinya terdapat pengaruh 
persepsi peserta didik atas kompetensi sosial guru terhadap hasil belajar di SMKN 12 Bekasi.

2) Jika $t_{\text {hitung }}<\mathrm{t}_{\text {tabel }}$, maka $H_{0}$ diterima dan $H_{1}$ ditolak artinya tidak

Terdapat pengaruh persepsi peserta didik atas kompetensi sosial guru terhadap hasil belajar di SMKN 12 Bekasi.

\section{RESULTS \& DISCUSSION}

\section{Results}

Penelitian ini dilakukan di SMKN 12 Bekasi yang beralamat di Jalan Kemang Sari IV RT. 003 RW. 011, Kelurahan Jatibening Baru, Kecamatan Pondok Gede, Kota Bekasi 17412. Untuk memperoleh data penelitian, maka peneliti menyebarkan angket ke 63 responden. Adapun hasil perhitungannya sebagai berikut :

\section{Tabel 2}

Perhitungan Regresi dan Korelasi Sederhana

\begin{tabular}{cccccc}
\hline No Responden & $\mathbf{X}$ & $\mathbf{Y}$ & $\mathbf{X}^{\mathbf{2}}$ & $\mathbf{Y}^{\mathbf{2}}$ & $\mathbf{X Y}$ \\
\hline 1 & 84 & 93 & 7056 & 8649 & 7812 \\
2 & 85 & 87 & 7225 & 7569 & 7395 \\
3 & 83 & 90 & 6889 & 8100 & 7470 \\
4 & 81 & 83 & 6561 & 6889 & 6723 \\
5 & 78 & 83 & 6084 & 6889 & 6474 \\
6 & 85 & 97 & 7225 & 9409 & 8245 \\
7 & 85 & 93 & 7225 & 8649 & 7905 \\
8 & 93 & 90 & 8649 & 8100 & 8370 \\
9 & 96 & 93 & 9216 & 8649 & 8928 \\
10 & 81 & 83 & 6561 & 6889 & 6723 \\
11 & 93 & 90 & 8649 & 8100 & 8370 \\
12 & 79 & 83 & 6241 & 6889 & 6557 \\
13 & 74 & 83 & 5476 & 6889 & 6142 \\
14 & 89 & 93 & 7921 & 8649 & 8277 \\
15 & 73 & 83 & 5329 & 6889 & 6059 \\
16 & 83 & 87 & 6889 & 7569 & 7221 \\
17 & 79 & 83 & 6241 & 6889 & 6557 \\
18 & 82 & 90 & 6724 & 8100 & 7380 \\
19 & 71 & 83 & 5041 & 6889 & 5893 \\
20 & 65 & 90 & 4225 & 8100 & 5850 \\
21 & 82 & 90 & 6724 & 8100 & 7380 \\
22 & 80 & 97 & 6400 & 9409 & 7760 \\
23 & 80 & 93 & 6400 & 8649 & 7440 \\
24 & 82 & 83 & 6724 & 6889 & 6806 \\
25 & 76 & 90 & 5776 & 8100 & 6840 \\
26 & 83 & 87 & 6889 & 7569 & 7221 \\
27 & 85 & 83 & 7225 & 6889 & 7055 \\
28 & 87 & 93 & 7569 & 8649 & 8091 \\
29 & 86 & 90 & 7396 & 8100 & 7740 \\
30 & 77 & 83 & 5929 & 6889 & 6391 \\
31 & 79 & 90 & 6241 & 8100 & 7110 \\
32 & 75 & 83 & 5625 & 6889 & 6225 \\
\hline & & & & &
\end{tabular}




\begin{tabular}{|c|c|c|c|c|c|}
\hline 33 & 75 & 87 & 5625 & 7569 & 6525 \\
\hline 34 & 85 & 90 & 7225 & 8100 & 7650 \\
\hline 35 & 77 & 87 & 5929 & 7569 & 6699 \\
\hline 36 & 75 & 90 & 5625 & 8100 & 6750 \\
\hline 37 & 76 & 83 & 5776 & 6889 & 6308 \\
\hline 38 & 77 & 90 & 5929 & 8100 & 6930 \\
\hline 39 & 74 & 87 & 5476 & 7569 & 6438 \\
\hline 40 & 69 & 90 & 4761 & 8100 & 6210 \\
\hline 41 & 77 & 93 & 5929 & 8649 & 7161 \\
\hline 42 & 81 & 97 & 6561 & 9409 & 7857 \\
\hline 43 & 80 & 90 & 6400 & 8100 & 7200 \\
\hline 44 & 79 & 87 & 6241 & 7569 & 6873 \\
\hline 45 & 75 & 83 & 5625 & 6889 & 6225 \\
\hline 46 & 80 & 80 & 6400 & 6400 & 6400 \\
\hline 47 & 83 & 93 & 6889 & 8649 & 7719 \\
\hline 48 & 81 & 90 & 6561 & 8100 & 7290 \\
\hline 49 & 87 & 97 & 7569 & 9409 & 8439 \\
\hline 50 & 76 & 90 & 5776 & 8100 & 6840 \\
\hline 51 & 78 & 87 & 6084 & 7569 & 6786 \\
\hline 52 & 76 & 90 & 5776 & 8100 & 6840 \\
\hline 53 & 69 & 83 & 4761 & 6889 & 5727 \\
\hline 54 & 76 & 80 & 5776 & 6400 & 6080 \\
\hline 55 & 75 & 80 & 5625 & 6400 & 6000 \\
\hline 56 & 80 & 90 & 6400 & 8100 & 7200 \\
\hline 57 & 80 & 90 & 6400 & 8100 & 7200 \\
\hline 58 & 80 & 87 & 6400 & 7569 & 6960 \\
\hline 59 & 84 & 90 & 7056 & 8100 & 7560 \\
\hline 60 & 81 & 90 & 6561 & 8100 & 7290 \\
\hline 61 & 82 & 87 & 6724 & 7569 & 7134 \\
\hline 62 & 78 & 90 & 6084 & 8100 & 7020 \\
\hline 63 & 78 & 93 & 6084 & 8649 & 7254 \\
\hline Jumlah & 5035 & 5560 & 404353 & 491902 & 444975 \\
\hline
\end{tabular}

Sumber: Diolah Peneliti, 2020

1. Regresi Linear Sederhana

Berikut hasil perhitungan regresi linear sederhana :

$$
\begin{aligned}
& a=\frac{\left(\sum Y\right)\left(\sum X^{2}\right)-\left(\sum X\right)\left(\sum X Y\right)}{n \cdot\left(\sum X^{2}\right)-\left(\sum X\right)^{2}} \\
& a=\frac{(5.560)(404.353)-(5.035)(444.975)}{63 \cdot(404.353)-(5.035)^{2}} \\
& a=\frac{2.248 .202 .680-2.240 .449 .125}{25.474 .239-25.351 .225} \\
& a=\frac{7.753 .555}{123.014} \\
& a=63,030 \\
& b=\frac{n \cdot\left(\sum X Y\right)-\left(\sum X\right)\left(\sum Y\right)}{n \cdot\left(\sum X^{2}\right)-\left(\sum X\right)^{2}}
\end{aligned}
$$




$$
\begin{aligned}
b & =\frac{63 \cdot(444.975)-(5.035)(5.560)}{63 \cdot(404.353)-(5.035)^{2}} \\
b & =\frac{28.033 .425-27.994 .600}{25.474 .239-25.351 .225} \\
b & =\frac{38.825}{123.014} \\
b & =0,316
\end{aligned}
$$

Sehingga ditemukan persamaan regresinya sebagai berikut:

$$
Y=63,030+0,316 X
$$

Maka dapat disimpulkan dimana nilai konstanta a atau nilai tetap 63,030, artinya pada saat pengaruh persepsi peserta didik atas kompetensi sosial guru sama dengan 0 maka hasil belajar sebesar 63,030 dan bila $b=0,316$ artinya setiap kenaikan $1 \%$ pada persepsi peserta didik atas kompetensi sosial guru, maka akan naik pula hasil belajar sebesar 0,316.

\section{Koefisien Korelasi}

Berikut hasil perhitungan Koefisien Korelasi :

$$
\begin{aligned}
& r_{x y}=\frac{\left(n \cdot \sum X Y\right)-\left(\sum X\right)\left(\sum Y\right)}{\sqrt{\left[n\left(\sum X^{2}\right)-\left(\sum X\right)^{2}\right]\left[n\left(\sum Y^{2}\right)-\left(\sum Y\right)^{2}\right]}} \\
& r_{x y}=\frac{(63)(444.975)-(5.035)(5.560)}{\sqrt{[63(404.353)-(25.351 .225)][63(491.902)-(30.913 .600)]}} \\
& r_{x y}=\frac{28.033 .425-27.994 .600}{\sqrt{[25.474 .239-25.351 .225][30.989 .826-30.913 .600]}} \\
& r_{x y}=\frac{38.825}{\sqrt{[123.014][76.226]}} \\
& r_{x y}=\frac{38.825}{\sqrt{9.376 .865 .164}} \\
& r_{x y}=\frac{38.825}{96.834,215} \\
& r_{x y}=0,401
\end{aligned}
$$

Maka dapat disimpulkan bahwa koefisien korelasi $\mathrm{r}_{\mathrm{xy}}=0,401$ artinya terdapat hubungan yang sedang antara persepsi peserta didik atas kompetensi sosial guru dengan hasil belajar.

3. Koefisien Determinasi

Berikut hasil perhitungan koefisien determinasi :

$$
\begin{aligned}
\mathrm{KD} & =\mathrm{r}^{2} \times 100 \% \\
\mathrm{KD} & =0,401^{2} \times 100 \% \\
\mathrm{KD} & =0,1608 \times 100 \% \\
\mathrm{KD} & =16.08 \%
\end{aligned}
$$

Hal ini berarti bahwa persepsi peserta didik atas kompetensi sosial guru memberikan kontribusi terhadap hasil belajar sebesar 16,08\% sedangkan sisanya $83,92 \%$ dipengaruhi oleh variabel lainnya. 
4. Pengujian Hipotesis

a. Menentukan $t_{\text {hitung }}$

$$
\begin{aligned}
t_{\text {hitung }} & =\frac{r \sqrt{n-2}}{\sqrt{1-r^{2}}} \\
t_{\text {hitung }} & =\frac{0,401 \sqrt{63-2}}{\sqrt{1-(0,401)^{2}}} \\
t_{\text {hitung }} & =\frac{3,131}{0,916} \\
t_{\text {hitung }} & =3,418
\end{aligned}
$$

Maka, diperoleh $t_{\text {hitung }}=3,418$

b. Nilai $\alpha$ dan $t_{\text {tabel }}$

Setelah diketahui nilai $t_{\text {hitung }}$ maka $t_{\text {hitung }}$ disandingkan dengan $t_{\text {tabel. }}$ Taraf signifikansi kesalahan yang digunakan $\alpha=10 \%$ uji dua sisi dan derajat kebebasan $(\mathrm{dk})=\mathrm{n}-2$. Maka, diperoleh $t_{\text {tabel }}=1,670$

c. Kriteria Pengujian

Kriteria pengujian dalam penelitian ini adalah:

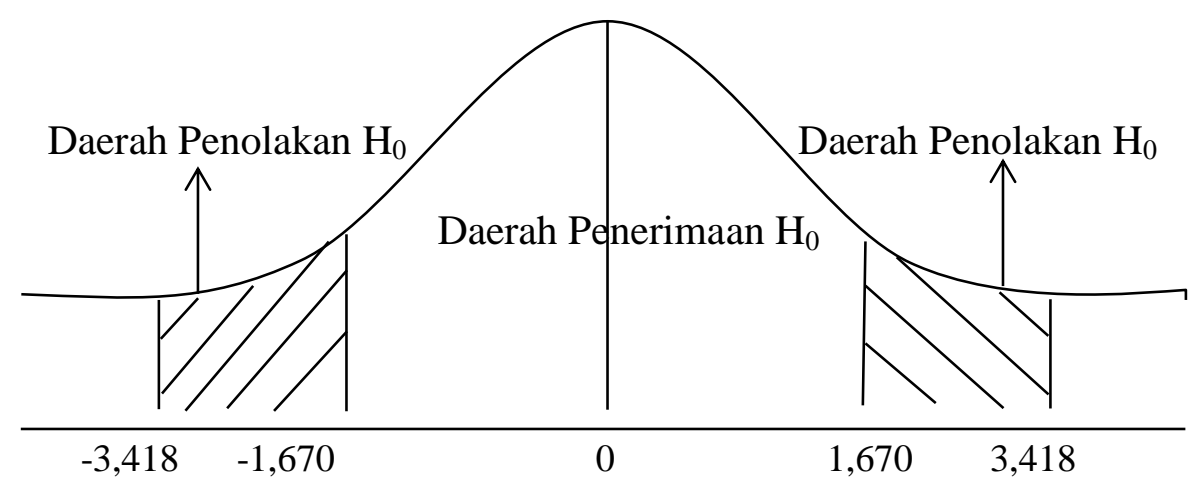

Sumber: Peneliti, 2020

Gambar 1.

Uji Signifikansi Dua Pihak

Dari hasil pengujian diatas menunjukkan bahwa $\mathrm{t}_{\text {tabel }} \alpha=10 \%$ untuk uji dua pihak $d k=n-2$ adalah $1,670, t_{\text {hitung }}>t_{\text {tabel }}(3,418>1,670)$ maka $H_{0}$ ditolak dan $H_{1}$ diterima. Sehingga terdapat pengaruh yang positif antara variabel $\mathrm{X}$ (persepsi peserta didik atas kompetensi sosial guru) terhadap variabel Y (hasil belajar) di SMKN 12 Bekasi.

\section{Discussion}

Hasil penelitian yang dilakukan kepada 63 responden melalui penyebaran dan pengolahan kuesioner serta menggunakan hasil belajar yang diambil dari nilai PTS ganjil menunjukkan bahwa terdapat pengaruh yang positif persepsi peserta didik atas kompetensi sosial guru terhadap hasil belajar, dibuktikan dengan nilai $t_{\text {hitung }}>t_{\text {tabel }}(3,418$ $>1,670)$. Hasil penelitian ini sesuai dengan penelitian yang dilakukan oleh Karlina dan Iswadi (2018), Syaidah, Umu dkk (2018), Marhento (2011). 


\section{CONCLUSION}

Berdasarkan temuan penelitian yang telah disajikan di atas, dapat ditarik

Setelah melakukan penelitian dan menganalisis data, maka data yang diperoleh memberikan hasil adanya pengaruh persepsi peserta didik atas kompetensi sosial guru terhadap hasil belajar mata pelajaran produk kreatif kewirausahaan di SMK Negeri 12 Kota Bekasi. Temuan ini memberikan keyakinan bahwa persepsi peserta didik memberikan pengaruh positif terhadap hasil belajar. Peserta didik mampu mengoptimalkan seluruh kemampuannya untuk mereduksi hal-hal yang menimpanya serta mengubahnya menjadi energi positif yang akan membangkitkan semangatnya untuk memperoleh hasil belajar yang optimal.

\section{REFERENCES}

Aunurrahman. (2010). Belajar dan Pembelajaran. Bandung: Alfabeta.

Daryanto. (2015). Pengembangan Karir Profesi Guru. Yogyakarta: Gaya Media.

Dimyati, Mudjiono. (2013). Belajar dan Pembelajaran. Jakarta: PT. Rineka Cipta.

Karlina, Elin dan Iswadi. (2018). Pengaruh Persepsi Siswa Atas Fasilitas dan Kompetensi Pedagogik Guru Terhadap Hasil Belajar Ekonomi Pada Siswa SMAN 21 Bekasi. Jurnal Research and Development Journal of Education, 4(2), 98-110.

Marhento, Giri. (2011). Pengaruh Persepsi Siswa Tentang Kompetensi Guru Mengajar dan Motivasi Belajar Terhadap Hasil Belajar IPA (Studi Pada SMP Se-Kecamatan Priuk Kota Tangerang Banten). Jurnal Formatif, 1(3), 223-235.

Jihad, dkk. (2013). Evaluasi Pembelajaran. Yogyakarta: Multi Pressindo.

Lestari, dkk. (2013). Strategi Belajar dan Pembelajaran. Jakarta: Unindra Press.

Musfah, J. (2011). Peningkatan Kompetensi Guru Melalui Pelatihan \& Sumber Belajar Teori dan Praktik. Jakarta: Kencana.

Payong, Marcel dkk. (2011). Sertifikasi Profesi Guru. Jakarta: PT. Indeks.

Sagala, S. (2013). Kemampuan Profesional Guru dan Tenaga Kependidikan. Bandung: Alfabeta.

Sardiman, A. M. (2012). Interaksi dan Motivasi Belajar Mengajar. Jakarta: PT. Raja Grafindo Persada.

Slameto. (2010). Belajar dan Faktor yang Mempengaruhi. Jakarta: Rineka Cipta.

Sudjana, N. (2017). Penilaian Hasil Proses Belajar Mengajar. Bandung: PT. Remaja Rosdakarya.

Syaidah, Umu dkk. (2018). Pengaruh Kompetensi Guru Terhadap Hasil Belajar Ekonomi di SMA Negeri Rambipuji Tahun Ajaran 2017/2018. Jurnal Pendidikan Ekonomi, 12(12), 185-191. 